\title{
Different pathways in the larval development of the crab Ucides cordatus (Decapoda, Ocypodidae) and their relation with high mortality rates by the end of massive larvicultures ${ }^{1}$
}

\author{
Ubiratã A.T. da Silva ${ }^{2 *}$, Kelly Cottens ${ }^{3}$, Robson Ventura ${ }^{4}$, Walter A. Boeger ${ }^{5}$ \\ and Antonio Ostrensky ${ }^{5}$
}

\begin{abstract}
Silva U.A.T., Cottens K., Ventura R., Boeger W.A. \& Ostrensky A. 2012. Different pathways in the larval development of the crab Ucides cordatus (Decapoda, Ocypodidae) and their relation with high mortality rates by the end of massive larvicultures. Pesquisa Veterinária Brasileira 32(4):284-288. Grupo Integrado de Aquicultura e Estudos Ambientais, Universidade Federal do Paraná, Rua dos Funcionários 1540, Curitiba, PR 80035-050, Brazil. E-mail: ubiratansilva@gmail.com

One of the most limiting factors affecting the larval rearing of Ucides cordatus in the laboratory is a period of high mortality, which usually occurs late in the course of the larviculture during the metamorphosis from the zoeal to the megalopal phase. The objective of the present research was to analyze the post-embryonic development of $U$. cordatus on an individual basis and, in particular, to search for patterns linking disturbances in the molting process to the high larval death rates observed in massive larvicultures. A total of 50 larvae were individually reared from hatching to metamorphosis into the megalopal phase under controlled conditions, fed a combination of microalgae and rotifers. The survivorship rate was $70 \%$ until zoea $\mathrm{V}$. The 35 surviving zoea $\mathrm{V}$ larvae followed two different pathways. Eleven underwent metamorphosis directly to megalopa, eighteen molted to zoea VI and six died as zoea V. In the last molting event, only two zoea VI larvae reached the megalopal stage, while the remaining sixteen died. In further observation under microscope, 13 of the dead zoea VI showed characteristics of the pre-molt stage and pereiopods disproportionably large in relation to the carapace. The observed pattern resembles the Molt Death Syndrome (MDS) described for other decapod species, in which larvae die in the late pre-molt phase of the molting cycle. We suggest that $U$. cordatus larvae develop disturbances in the molting process similar to the MDS described for other species and that these disturbances are related to a more complex pathway involving the emergence of larval stage zoea VI.
\end{abstract}

INDEX TERMS: Larva, larviculture, mangrove crab, Molt death syndrome.

RESUMO.- [Diferentes rotas de desenvolvimento larval do caranguejo Ucides cordatus (Decapoda, Ocypodidae) e sua relação com altas taxas de mortalidade no fim de

\footnotetext{
${ }^{1}$ Received on November 5, 2011.

Accepted for publication on November 16, 2011.

${ }^{2}$ Centro de Estudos do Mar, Universidade Federal do Paraná, Av. Beira-mar s/n, Cx. Postal 50002, Pontal do Sul, Pontal do Paraná, PR 83255000, Brazil

${ }^{3}$ Instituto Chico Mendes de Conservação da Biodiversidade, Av. Nazeazeno s/n, Bragança, PA 68600-000, Brazil.

${ }^{4}$ Centro de Desenvolvimento em Aqüicultura e Pesca (Cedap), Empresa de Pesquisa Agropecuária e Extensão Rural de Santa Catarina (Epagri), Rodovia Admar Gonzaga 1118, Cx. Postal 502, Itacorubi, Florianópolis, SC 88034-901, Brazil. *Corresponding author: ubiratansilva@gmail.com

${ }^{5}$ Grupo Integrado de Aquicultura e Estudos Ambientais (GIA), Universidade Federal do Paraná, Rua dos Funcionários 1540, Juvevê, Curitiba, PR 80 035-050, Brazil
}

larviculturas massivas.] Um dos fatores mais limitantes que afetam o cultivo larval de Ucides cordatus (Linnaeus, 1763) em laboratório é um período de alta mortalidade, o qual usualmente ocorre no fim do curso da larvicultura durante a metamorfose da fase de zoea para a de megalopa. 0 objetivo da presente pesquisa foi analisar o desenvolvimento pósembrionário de $U$. cordatus em uma base individual e, em particular, procurar por padrões ligando distúrbios no processo de muda com as altas taxas de mortalidade observadas nas larviculturas massivas. Um total de 50 larvas foram cultivadas individualmente da eclosão até a fase de megalopa em condições controladas, alimentadas com uma combinação de microalgas e rotíferos. A taxa de sobrevivência foi de $70 \%$ até zoea V. As 35 larvas zoea V sobreviventes seguiram dois diferentes caminhos. Onze realizaram a metamorfose diretamente para megalopa, dezoito 
mudaram para zoea VI e seis morreram como zoea V. No último evento de muda, apenas duas larvas zoea VI atingiram a fase de megalopa, enquanto as dezesseis restantes morreram. Em investigação posterior sob microscópio, 13 das zoea VI mortas mostravam características de estágio de prémuda e pereiópodes desproporcionalmente grandes em relação à carapaça. 0 padrão observado lembra a Síndrome da Morte na Muda (MDS) descrita para outras espécies de decápodes, na qual larvas morrem no fim da fase de prémuda do ciclo de mudas. Nós sugerimos que larvas de $U$. cordatus desenvolvem distúrbios no processo de muda similares à MDS descrita para outras espécies e que esses distúrbios são relacionados a um caminho mais complexo que envolve a ocorrência do estágio larval zoea VI.

TERMOS DE INDEXAÇÃO: Larva, larvicultura, caranguejo do mangue, síndrome da morte na muda.

\section{INTRODUCTION}

The mangrove crab Ucides cordatus (Linnaeus, 1763) has a wide geographical distribution along the western Atlantic coast, from Florida (USA) to the Brazilian state of Santa Catarina. This crab is considered an important fishery resource for local populations throughout the Brazilian coast, particularly those surrounding estuarine systems (Glaser 2003).

The combination of overfishing, degradation of the mangrove habitat and, more recently, the Lethargic Crab Disease (LCD) has contributed to a drastic reduction of natural stocks of $U$. cordatus in several regions of Brazil (Boeger et al. 2005). In addition to more classical measures, such as minimum carapace size policies and the prohibition of capture during reproductive periods, a possible alternative to help recover these populations is the mass production of young forms in laboratory, followed by their release directly into the affected areas.

Large-scale larval cultures of the mangrove crab U. cordatus have been conducted by our research group during the natural reproductive period of the animal as part of an institutional program of restocking this species in coastal areas of Brazil since 2001. During this period, several issues related to this technology were investigated, such as larvicultural methods (Silva et al. 2006, 2009), food protocols for larvae (Becker et al. unpublished results), cannibalism and intraspecific antagonistic interactions (Ventura et al. 2008, 2011). One of the most limiting factors affecting the larviculture efforts is a period of high mortality, which usually occurs late in the course of the larviculture during the metamorphosis from zoeal to the megalopal stage. In some events, up to $90 \%$ of the cultivated larvae are lost in a few days. The larviculture of other species of brachyuran crabs, lobster and crayfish suffer from similar mortality (Sulkin \& Norman 1976, Paul et al. 1989, Sulkin et al. 1998, Mann et al. 2001, Ruscoe et al. 2004), in which large quantities of larvae die at about the same time, especially near the end of the larviculture cycle. One striking resemblance among these reports is that most dead larvae present mixed morphological traits, between the stages of zoea and decapodid, suggesting that the phenomenon may be rela- ted to difficulties arisen during the molting process. The term "exuvia entrapment disease" (EED) was suggested by Brock (1983) to describe this phenomenon, whereas the term "molt death syndrome" (MDS) was suggested by Bowser \& Rosemark (1981). We use the more standard term MDS in this manuscript.

Different hypotheses have been proposed to explain MDS, ranging from nutritional problems to the chemical composition of the water. Coutteau et al. (1997) reported significant reductions in the incidence of MDS with the addition of soy lecithin to the diet of larval Homarus americanus Milne Edwards, 1837. D'Abramo et al. (1981) suggested the addition of phosphatidylcholine for the same purposes. However, Brock (1988) indicated that high concentrations of calcium carbonate could promote crystal deposits on the inner surface of exuvia, hindering its release by the larva and thus triggering MDS. Although the larviculture of $U$. cordatus, for academic or scientific purposes, is currently being pursued by different institutions, there are still no reports of the occurrence of MDS in larvae of this species in the literature.

Rodrigues \& Hebbling described the larval development stages of $U$. cordatus in 1989 and two pathways were observed: larvae that reached the megalopal stage underwent six stages (zoea I to VI) and larvae that reached the megalopal phase directly from the zoea $V$ stage. Their research was focused in describing the anatomical peculiarities of each stage and do not include any description of the dead larvae. We hypothesized that the occurrence of MDS in U. cordatus would be related to one of these pathways. The objective of the present research was to analyze the post-embryonic development of $U$. cordatus on an individual basis and, in particular, to search for patterns linking disturbances in the molting process to the observed high larval death rates.

\section{MATERIALS AND METHODS}

Larvae used in the experiments were obtained from ovigerous females of Ucides cordatus collected from mangroves in Antonina, state of Paraná, Southern Brazil (2524’57”S, 4843’06”W). Collected females were brought to the laboratory, where they were maintained in 1000-L plastic tanks filled with seawater under controlled environmental conditions $\left(26^{\circ} \mathrm{C}, \mathrm{pH}\right.$ of 8 , and salinity $26 \mathrm{psu}$ ) until the larvae hatched, which occurred without any artificial stimulus.

Experimental observations were conducted under a controlled temperature $\left(26^{\circ} \mathrm{C}\right)$ and photoperiod (16h:8h LD cycle). The larvae from several females hatched, all in stage zoea I. These larvae were randomly transferred to 50 individual vials filled with $30 \mathrm{ml}$ of seawater (salinity $26 \mathrm{psu}$ ). Environmental conditions used in the assay were based on the methodology proposed by Silva et al. (2006), thus providing similar conditions for the occurrence of mortalities such as those observed in massive larviculture of $U$. cordatus . Larvae were provided with a combination of the microalga Nannochloropsis oculata (Droop) D.J. Hibberd (12×10 cells. $\mathrm{mL}^{-1}$ ) and the rotifer Brachionus plicatilis Mueller, 1786 (6 rotifers. $\mathrm{mL}^{-1}$ ) (feeding protocol presently used at LAPOA for massive larvicultures of this species).

Considering that the analysis under microscope would damage live larvae, the determination of the date of molt and of the larval stages was based on the analysis of exuviae and dead larvae. Each day, each larva was carefully transferred to a new vial contai- 
ning clean water and fresh food. During the transference procedure, a search for exuviae was performed. Exuviae and dead larvae were stored in $70^{\circ} \mathrm{C}$ glycerinated ethanol. Observations were finished after all larvae had died or reached the megalopa phase.

The collected exuviae and dead larvae were assembled on semi-permanent slides with the use of transparent enamel, and were photographed under optical microscopy. Larval stages of $U$. cordatus were determined according to the morphological descriptions proposed by Rodrigues \& Hebling (1989).

\section{RESULTS}

The entire experiment lasted 36 days. The survival rate of larvae at the zoea $\mathrm{V}$ stage was $70 \%$ (Table I). Over the course of the experiment, a steep decline in survivorship was observed. After reaching the zoea V stage, larval development followed two distinct pathways (Fig.1). Of the 35 surviving larvae at the zoea $V$ stage, 11 metamorphosed directly into megalopa (dashed line, Fig.1), 6 died without reaching the next stage and 18 molted into zoea VI (solid line, Fig.1). Only 2 larvae successfully molted from zoea VI to the megalopa stage.

Comparing curves of survivorship for each stage, it was apparent that stages zoea VI and megalopa appeared concurrently, as opposed to the other stages which occurred sequentially over the course of larval development (Fig.2). Examining dead zoea and exuviae under a microscope revealed distinct features among zoea $\mathrm{V}$ larvae, and there were morphological differences between individuals on different life history trajectories. Larvae that became megalopae were generally larger than those that molted to stage

Table 1. Ucides cordatus (Linnaeus, 1763) larvae survivorship observed in the assay

\begin{tabular}{ccc}
\hline Stage & Larvae alive & $\begin{array}{c}\text { Percentage } \\
\text { survival }\end{array}$ \\
\hline Zoea I & 50 & 100 \\
Zoea II & 42 & 84 \\
Zoea III & 40 & 80 \\
Zoea IV & 39 & 78 \\
Zoea V & 35 & 70 \\
Zoea VI & 18 & 38 \\
Megalopa & $13 *$ & 26 \\
*11 megalopae derived directly from zoea V and \\
two from zoea VI.
\end{tabular}

zoea VI. The most obvious morphological difference between the two morphotypes is a difference in the uropods present over the sixth pleonite. Larvae that would become megalopae showed a prominent pair of uropods, whereas larvae that would become zoea VI showed only vestigial lumps (Fig.3).

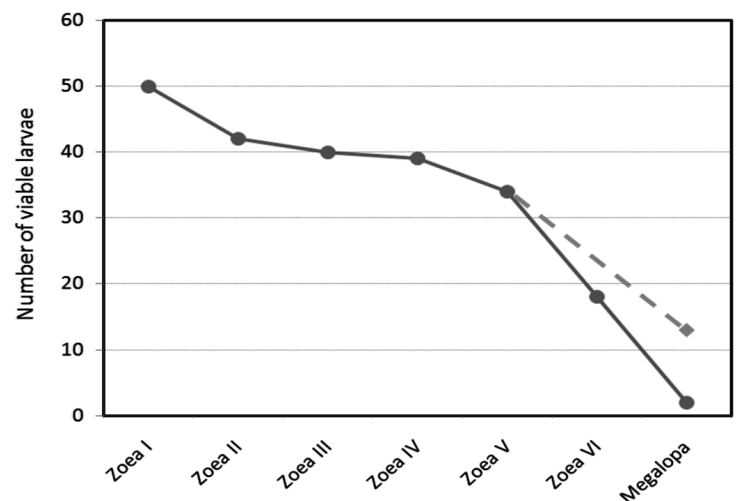

Fig.1. Different Ucides cordatus (Linnaeus, 1763) larval development pathways observed. Dashed line indicates the pathway in which larvae go from zoea V stage directly to megalopa, and the continuous line represents the most complex pathway that involves a supernumerary stage, zoea VI.

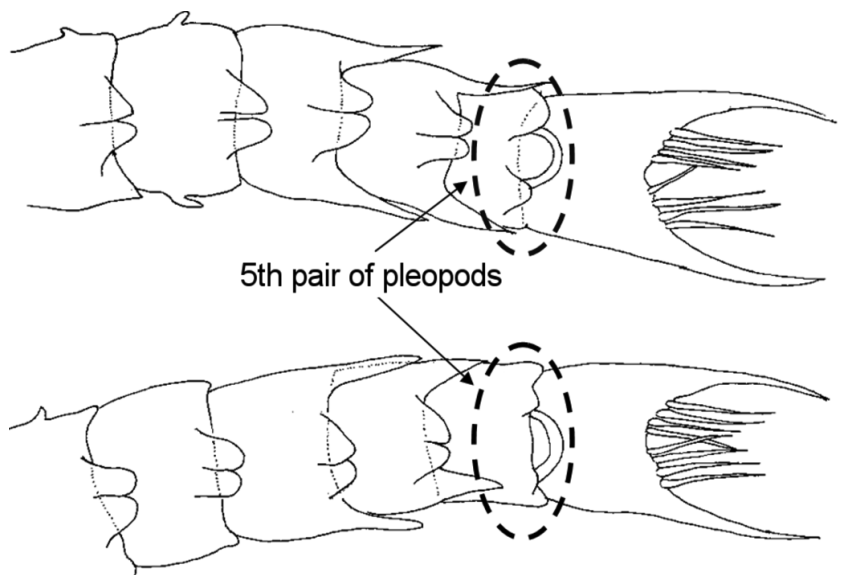

Fig.3. Morphological differences between Ucides cordatus (Linnaeus, 1763) zoea $\mathrm{V}$ larvae that became megalopae (above) and those that molted to the stage of zoea VI (below). In particular, the shape of the pleopods is the most easily discernible feature between the variants.

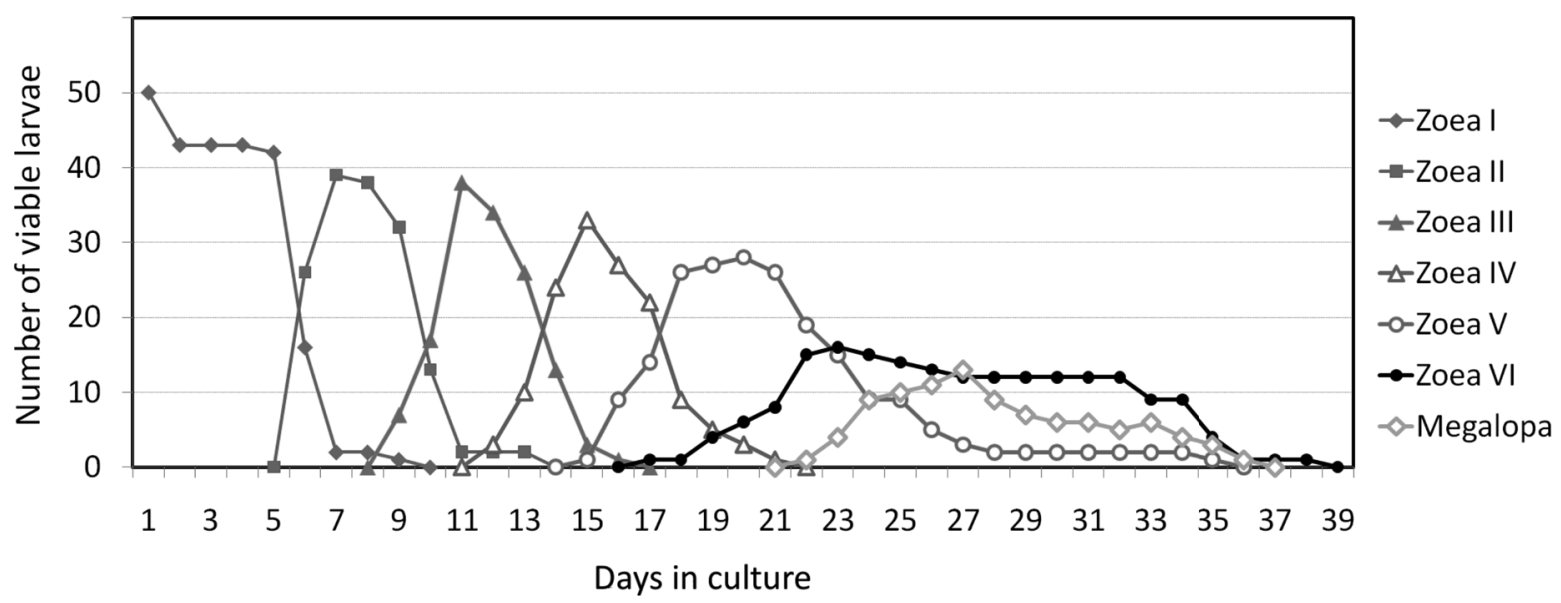

Fig.2. Survivorship of Ucides cordatus (Linnaeus, 1763) larval stages observed during the assay. 


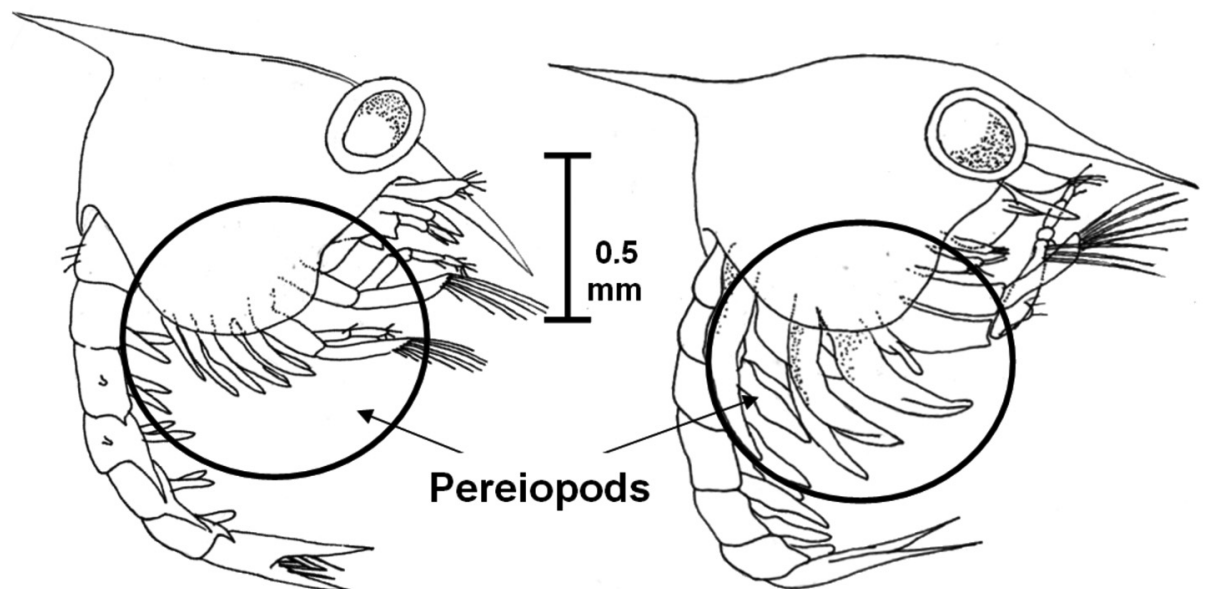

Fig.4. Comparison between an Ucides cordatus (Linnaeus, 1763) larva at zoea VI stage, as described by Rodrigues \& Hebling (1989) (left), and a zoea VI that died during the experiment (right). The pereiopod of the latter is disproportionably large in relation to the carapace in comparison to the former.

When the 16 dead zoea VI larvae were analyzed under the microscope, 13 showed characteristic of the pre-molt stage according to the molt cycle described by Anger (2001). When one compares these individuals with the zoeae VI described by Rodrigues \& Hebling (1989), it becomes clear that the pereiopods of the former are disproportionably large in relation to the carapace (Fig.4).

The average time from hatching until metamorphosis to megalopa was 25.3 days. The first megalopa was detected on the 22nd day of cultivation and by the 27 th day, most of the metamorphosis to megalopa had already occurred. The last metamorphosis to megalopa occurred on the 33rd day of cultivation.

\section{DISCUSSION}

The survivorship rates observed in our assay (26\% until the megalopal phase) were lower than those obtained by Rodrigues \& Hebling (1989) that obtained a survivorship rate of $75 \%$ until the megalopa phase. We observed a tendency of higher mortalities of zoea $V$ larvae that passed through the sixth zoeal stage $(2$ survivor megalopae from 18 Zoea $\mathrm{VI}=88.8 \%$ of mortality rate from zoea V until megalopa) in despite of those which went directly into the megalopal phase. Even if all the zoea $V$ larvae that died before reaching the next stage were assumed as intending to molt directly to the megalopal phase, the mortality rate of this group would be still lower (11 survivor megalopae from 17 Zoea $\mathrm{V}=35.2 \%$ of mortality) than that observed for larvae which passed through the zoea VI stage.

Several authors have described alternative pathways in the development of larval decapod crustaceans and the presence of supernumerary stages has been pointed as an adaptation to adverse environmental conditions (Costlow 1965, Sandifer \& Smith 1979, Makarov \& Maslennikov 1981, Montú et al. 1990, Anger 2001). It is important to note that in their literature review, Rodrigues \& Hebbling (1989) stated that seven out of nine members of Ocypodidae present five stages of zoea instead of six, suggesting that the most common way of developing Ucides cordatus could involve five stages of zoea instead of six. Zeng et al. (2004), working with the larviculture of Scylla paramamosain (Estampador 1949), noted the emergence of a sixth larval stage, when only five stages were described for the species in the literature. The authors in that study used different combinations of two different diets, one based on enriched rotifers and another based on Artemia nauplii, with sequential densities of these food items. In their experiments, the supernumerary stage appeared in treatments with the worst performance and was correlated to low survival rates. Based on literature reports and on our findings, which points to low survivorship of larvae which underwent the most complex pathway, we suggest the sixth zoeal stage in $U$. cordatus as a supernumerary stage.

Pestana \& Ostrensky (1995), working with Chasmagnathus granulata (Dana 1851), reported the emergence of a fifth supernumerary stage only in larval cultures where lower survival rates were observed. The authors also noted that the zoea IV larvae, which would undergo metamorphosis directly to megalopa, were larger than those that would molt to the supernumerary fifth stage. Similar results were observed in the present work. We noted that most of Zoea IV that followed the most complex larval pathway was smaller than those who underwent five zoeal stages and specific morphological peculiarities were also observed. Considering that our results indicate a narrow relation among survivorship of larvae and the larval pathway followed, our findings could be useful clues to forecast the survivorship of larviculture batches.

Finally, we observed that most of the larvae that die at the zoea VI stage appeared to be at pre-molt stage according to the molt cycle described by Anger (2001). Moreover, the morphological characteristics of these dead zoea VI larvae were very similar to those described by other authors as MDS (Hamasaki et al. 2002).

Our results indicate the emergence of a sixth stage of zoea before megalopa in the development of $U$. cordatus could also be seen as an alternative life history. Considering that both the environmental and nutritional requirements 
of $U$. cordatus larvae are insufficiently known, experiments testing different environmental conditions and evaluating both survivorship and the occurrence of the sixth zoeal stage could be performed in order to determine which conditions trigger the occurrence of the alternative pathway. Based on our results, we suggest that $U$. cordatus larvae develop disturbances in the molting process similar to MDS and that these disturbances are related to a more complex pathway involving the emergence of larval stage zoea VI.

\section{REFERENCES}

Anger K. 2001. The Biology of Decapod Crustacean Larvae. Balkema Publishers, Rotterdam, Netherlands, p.1-420.

Boeger W.A., Pie M.R., Ostrensky A. \& Patella L. 2005. Lethargic crab disease: multidisciplinary evidence supports a mycotic etiology. Mem. Inst. Oswaldo Cruz 100(2):161-167.

Bowser P.R. \& Rosemark R. 1981. Mortalities of cultured lobsters, Homarus sp., associated with a molt death syndrome. Aquaculture 23(1/4):11-18.

Brock J.A. 1983. Diseases (infectious and non-infectious), metazoan parasite, predators and public health considerations in Macrobrachium culture and fisheries, p.329-370. In: McVey J.P. (Ed.), CRC Handbook of Mariculture. Vol.1. Crustacean Aquaculture. CRC Press, Florida.

Brock J.A. 1988. Exuvia entrapment disease of Macrobrachium rosenbergii larvae, p.142-144. In: Sinderman C.J., Lightner D.V. (Eds), Disease Diagnosis and Control in North American Marine Aquaculture. Elsevier Scientific Publishing Company, Amsterdam.

Costlow J.D. \& Bookhout C.G. 1959. The larval development of Callinectes sapidus (Rathbun) reared in laboratory. Biol. Bull. 116(3):373-396.

Coutteau P., Geurden I., Camara M.R., Bergot P. \& Sorgeloos P. 1997. Review on the dietary effects of phospholipids in fish and crustacean larvicultura. Aquaculture 155:149-164.

D’Abramo L.R., Bordner C.E., Conklin D.E. \& Baum N.A. 1981. Essentiality of dietary phosphatidylcholine for the survival of juvenile lobsters. J. Nutr. 3(111):425-431.

Gläser M. 2003. Interrelations between mangrove ecosystem, local economy and social sustainability in Caeté Estuary, North Brazil. Wetl. Ecol. Manage. 11(4):265-272.

Hamasaki K., Suprayudi M.A. \& Takeuchi T. 2002. Effect of dietary n-3HUFA on larval morphogenesis and metamorphosis to megalops in the seed production of mud crab, Scylla serrata (Brachyura: Portunidae). Susian Zoshoku 50:333-340.

Makarov R.R. \& Maslennikov V.V. 1981. Ecology of larval development of the crustacean Euphasusia superba. Change in dominant larval forms as a function of environmental conditions. Mar. Ecol. Prog. Ser. 4:265-271.
Mann D.L., Asakawa T., Pizzutto M., Keenan C.P. \& Brock I.J. 2001. Investigation of an Artemia-based diet for Larvae of the Mud Crab Scylla serrata. Asian Fish. Sci. 14:175-184.

Montú M., Anger K., Debakker C. 1990. Variability in the larval development of Metasesarma rubripes_(Decapoda, Grapsidea) reared in the laboratory. Nerítica 5:113-128.

Paul A.J., Paul J.M. \& Coyle K.O. 1989. Energy sources for first-feeding zoeae of king crab Paralithodes camtschatica (Tilesius) (Decapoda, Lithodidae). J. Exp. Marine Biol. Ecol. 130:55-69.

Pestana D. \& Ostrensky A. 1995. Occurrence of an alternative pathway in the larval development of the crab Chasmagnathus granulata (Dana, 1851) under laboratory conditions. Hydrobiologia 306:33-40.

Rodrigues M.D., Hebling N.J. 1989. Ucides Cordatus (Linnaeus, 1763) (Crustacea, Decapoda) complete larval development under laboratory conditions and its systematic position. Revta Bras. Zool. 1(6):147166.

Ruscoe I.M., Williams G.R. \& Shelley C.C. 2004. Limiting the use of rotifers to the first zoeal stage in mud crab (Scylla serrata, Forskål) larval rearing. Aquaculture 231:517-527.

Sandifer P.A. \& Smith T.I.J. 1979. Possible significance of variation in the larval development of the palaemonid shrimps. J. Exp. Marine Biol. Ecol. 39:55-64.

Silva U.A.T., Ostrensky A., Ventura R., Santos A.F. \& Boeger W.A. 2006. A produção de caranguejo-uçá em laboratório. Panorama da Aqüicultura 94:15-21.

Silva U.T.A., Ramos F.M., Ventura R., Coelho Neto A., Boeger W.A. \& Ostrensky A. 2009. A produção de larvas de caranguejo-uçá em sistema de cultivo em mesocosmos. Panorama da Aqüicultura 113:24-28.

Sulkin S.D. \& Norman K. 1976. A comparison of two diets in the laboratory culture of the zoeal stages of the brachyuran crabs Rhithropanopeus harrisii and Neopanope sp. Helgoland Mar. Res. 28:183-190.

Sulkin S., Lehto J., Strom S. \& Hutchinson D.S. 1998. The nutritional role of protists in the first stage larvae of the Dungeness crab, Cancer magister. Mar. Ecol. Prog. Ser. 169:237-242.

Ventura R., Silva U.T.A., Perbiche-Neves G., Ostrensky A., Boeger W.A. \& Pie M.R. 2008. Larval cannibalism rates in the mangrove crab Ucides cordatus (Decapoda: Ocypodidae) under laboratory conditions. Aquaculture Res. 39:263-267.

Ventura R., Silva U.A.T., Ostrensky A. \& Cottens, K. 2011. Intraspecific interactions in the mangrove crab Ucides cordatus (Decapoda: Ocypodidae) during the metamorphosis and post-metamorphosis periods under laboratory conditions. Zoologia 28(1):1-7.

Zeng C., Li S. \& Zeng H. 2004. Occurrence of additional zoea-VI larvae in the mud crab, Scylla paramamosain (Estampador), reared in the laboratory. Hydrobiologia 529:49-58. 